production 54 per cent. This was accompanied by an increase of 30 per cent in the resting pulse or heart-rate, 34 per cent in the resting respiration-rate, and a slight increase in the rectal temperature. In one of these experiments, no extra food was given to the cows to compensate for the increased metabolism, and, after seven weeks feeding with $50 \mathrm{gm}$. a day, the cows had lost $115 \mathrm{lb}$. of body weight or 9 per cent of their original weight. The shape of the weight-loss curve and the condition of the cows suggested that, in the latter stages of treatment, tissue protein was being mobilized to meet the increased energy requirement. Even after seven weeks treatment at such a high level, the clinical abnormalities shown by the cows were not so severe as was expected, and when treatment was stopped liveweight was rapidly regained. The subsequent history, performance, and postmortem appearance of animals subjected to such drastic treatment does not indicate that their health has been impaired.

Iodinated casein has been used in four experiments. It has been found that the response in milk production to a standard dose $(30 \mathrm{gm}$.) of a highly thyroidactive preparation is dependent on the initial level of production of the cow. The response in pounds per day is greater the higher the initial yield $(r=+0.7874)$, but the percentage response declines with increasing initial yield $(r=-0 \cdot 4668)$. As the main factor causing initial yield variation in these experiments was the stage of lactation of the cow, it is thought that response varies with the stage of lactation. This has been confirmed by experiments on the same cow at different lactation stages. The effect of lactation stage is interpreted as indicating a lower state of functional activity per unit of active mammary tissue during late lactation, and a larger amount of active mammary tissue in a higher state of functional activity in early lactation in the normal cow. It has not, however, proved possible to prolong, by iodinated casein feeding, milk production in cows approaching the end of their normal lactation period. Heifers and cows have responded equally well, no response differences have been found between cows at pasture and cows kept on winter rations, and Guernsey and Shorthorn cows have responded in a very similar manner.

It has been found that a dose of $15 \mathrm{gm}$. daily of iodinated casein increases milk production by approximately 16 per cent and $30 \mathrm{gm}$. daily by 33 per cent, indicating that the percentage response in milk production is directly proportionate to dosage within this range. The heart-rate increase and the percentage heart-rate increase, however, are nearly trebled by doubling the dosage, this probably indicating that at low dose-levels the increased metabolism is not reflected in an increase in the heart-rate. The relationship between the milk-yield response and the heart-rate response to iodinated proteins of different potencies confirms that at low milk-yield responses the heart-rate responses are proportionally lower than when the milk-yield response is high.

The galactopoietic potencies of iodinated proteins have been expressed in terms of the percentage increase in milk production per gram of iodinated protein fed. Potencies of 0.075 per cent for iodinated blood, 0.543 per cent for iodinated 'Ardein', and up to 1.096 per cent for iodinated casein have been found. There is a distinct, but not exact, relationship between the acid-insoluble ('thyroxine') iodine analysis of iodinated proteins and their galactopoietic potencies, but much better agreement with lactation response is shown by biological assays carried out with Xenopus tadpoles by Dr. A. S. Parkes.

Since the work was commenced, Reineke and Turner ${ }^{10}$ have published the results of three-day feeding trials with dairy cows, using their own iodinated casein preparations. The results of these shortterm trials also indicate that the milk production of cows can be stimulated by feeding iodinated casein.

The results reported above, together with much additional data on milk composition and the clinical effects of dosage, will be published later. Experiments are now in progress to find whether practical application of the results is possible, especially with regard to winter milk production.

My thanks are due to the Agricultural Research Council for grants in aid of this work.

Dairy Husbandry Department,

K. L. BLaxter.

National Institute for

Research in Dairying, Shinfield.

Nov. 20.

I Graham, W. R., jun., J. Nutrition, 1, 407 (1934)

Graham, W. R., jun., Biochem. J., 28, 1368 (1934).

'Folley, S. J., and White, P., Proc. Roy. Soc., B, 120, 346 (1936).

- Herman, H. A., Graham, W. R., jun., and Turner, C. W., Oniv. Missouri Res. Bull., 275 (1938).

- Morse, M., J. Biol. Chem., 19, 421 (1914).

- Ludwig, V., and von Mutzenbecher, P., Z. physiol. Chem., 258, 195 (1939).

${ }^{7}$ Harington, C. R., and Pitt Rivers, R. V., NATURE, 144, 205 (1939). B Report of the National Institute for Research in Dairying (1940), 35. - Bottomley, A. C., and Folley, S. J., private communication (1941). ${ }^{10}$ Reineke, E. P., and Turner, C. W., J. Dairy Sci., 25, 393 (1942).

\section{A Scientific Directory}

IN recent months much has been said about the organization of science and, without prejudice to, or support for, any particular formula, there is one direction in which effect can be given in some measure to that aim, namely, in the provision for the British Commonwealth of a directory of scientists along the lines of "American Men of Science"1. Such a directory should be available in public libraries and research institutions and should serve to group together, in a manner hitherto entirely overlooked, those members of the community who conduct original investigations in the natural and exact sciences in any of the recognized branches. The concise style of entry, apart from the contentious practice of 'starring', adopted in "American Men of Science" is admirable for conveying the information that scientists have a right to expect to have regarding each other, and much would be gained in reducing the insularity felt by members of one branch vis-à-vis those of another.

The responsibility for the production of such a directory is beyond the purview of any of the scien. tific societies except perhaps the Royal Society, and it might not be too much to hope that the experience gained with the Central (Scientific) Register of the Ministry of Labour during the past few years could be made available for the project envisaged once stable conditions return at the end of the War.

National Institute for Medical Research, JAMES WALKER. London, N.W.3.

1 "American Men of Science, A Biographical Directory". 1st Edn, 1906; 6th Edn., New York, 1938; 7th Edn., in preparation. 